\title{
THE SOUTH CHINA SEA IMPASSE AND IMPLICATIONS FOR WORLD POLITICS
}

\section{Sheriff Ghali Ibrahim and Esther Nuhu}

University of Abuja; Nile University of Nigeria

Email: sherfboy@yahoo.com; Phone: +234-7063372013

\section{Cite this article:}

Sheriff G.I., Esther N. (2021), The South China Sea Impasse and Implications for World Politics. African Journal of Law, Political Research and Administration 4(2), 53-60. DOI: 10.52589/AJLPRAY3RLQCOG.

\section{Manuscript History}

Received: 16 June 2021

Accepted: 5 July 2021

Published: 17 Aug 2021

Copyright $\odot 2020$ The Author(s). This is an Open Access article distributed under the terms of Creative Commons AttributionNonCommercial-NoDerivatives 4.0 International (CC BY-NC-ND 4.0 ), which permits anyone to share, use, reproduce and redistribute in any medium, provided the original author and source are credited.
ABSTRACT: The paper examines the South China Sea impasse between China and its neighbours in the region as well as the United States, which tries to see the sea as an open maritime area for international navigation. Using the secondary documented literature, findings show that the South China Sea is naturally endowed with variegated natural resources ranging from oil, gas and habitable islands that can be developed and this is the reason behind the impasse. The paper concludes that the South China Sea is increasingly a hotspot of conflict between China and the US; it is the subject of several overlapping territorial disputes. Like in most geopolitical tensions, trade would be a prime casualty in case of an escalation. The paper recommends that China, which is the claimant of the South China Sea, and other countries involved should dialogue and come up with policies that are favourable to all parties involved.

KEYWORDS: South China; Sea; Impasse; Conflict; Geopolitics; Political Strategy. 


\section{INTRODUCTION}

The South China Sea (in Mandarin Nán zhōngguó hãi) is a semi-confined area that encompasses Spratyls and Paracels. Brunei, China, Malaysia, the Philippines, Taiwan and Vietnam all have competing - in some cases overlapping - claims to the sea. The South China Sea is rich in hydrocarbon, oil, natural gas and fish stocks. It has one of the busiest shipping lanes in the world. China was once in charge of the sea but other countries have claimed rights to it too. The US has trade routes worth hundreds of millions of dollars on the sea. The South China Sea was ignored by the claimant for a while until the 21 st century. It was not regarded as an important and threatening area but ever since the claimant realized the importance of the sea, it is now often seen as a theatre of military tension and dangerous conflict potential. The US has been committed to the idea of the freedom of the seas and that has been a great threat to the sea. The South China Sea conflict is a much more complex matter involving political developments, environmental values, and economic security, and so cannot be reduced to conventional military security alone. For the ordinary citizens of the countries that are involved, the area is first and foremost a source of seafood and a transportation route. Both the safety of sea lanes and the management of fisheries are fundamentally affected by the conflict of sovereignty over territories in the South China Sea.

The interest of the disputant nations in the territorial disputes in the South China Sea is tied to their political, economic, environmental and military concerns. In terms of military security, there are reasons to claim that for many of these nations, the disputes over territories in the South China Sea constitute 'the least unlikely' trigger for inter-state war. In general, territorial disputes have proved to be the principal motive for interstate warfare, while more specifically, the statistics of militarised interstate disputes show the area to be no exception in this regard. The importance of these disputes in regional security considerations is paramount. Indeed, while institutionalisation of the security arrangements in the South China Sea area is rather underdeveloped, the disputes over the sea have motivated collective security arrangements even among some of the non-aligned nations.

For the external involved powers, such as the United States and Japan, the South China Sea presents a problem of economic, diplomatic, environmental and military stability. With the exception of direct military threat, many of the same worries experienced by the disputants are also felt, albeit to a lesser extent, by the United States and Japan. This has been clearly expressed in the military and diplomatic tension, as well as in the qualified nervousness of the markets dependent on the South China Sea. The South China Sea has become meaningful also for the non-involved nations such as those in the European Union. This interest is often based on considerations of global security policies: the economic, ecological and social threats caused by the prospect of war or ecological disaster in the area.

New global security policies are based on national security considerations. Political, economic and military interests are interlinked with global security interests and this is why even faraway countries have to follow developments in places like the South China Sea. National security policies of most nations are today more than ever based on a broad, comprehensive and global concept of security. National security policies are concretely influenced by the development of global international tension. International tension is also seen to reflect on regional tensions and global threats of war. Moreover, today, the threat of uncontrolled migration, refugee problems, international criminality, the spread of drugs and small arms, epidemics, and religious fundamentalism are seen as factors influencing national security — often created by 
global insecurity and wars. Furthermore, national economic security can easily be affected by conflicts at the major hubs of international trade routes, such as the South China Sea. Comprehensive global security policy issues, such as global environmental challenges, directly affect the national security of all countries. While global environmental challenges as such might be security threats, the disputes in the South China Sea also prove how they might very well be connected with more traditional security threats. While the sovereignty of the areas is disputed, this unclear situation is rapidly giving rise to environmental challenges.

Global security policies have been developed outside the national security policy context in the framework of the promotion of peace via the instruments offered by development cooperation. By supporting democracy, human rights and economic development, as well as helping developing countries to build institutions for dispute settlement and conflict transformation, aid donor countries have attempted to contribute to global security. Many countries and agencies with a serious commitment to development cooperation have already started to draw up their conflict prevention strategies as part of their development cooperation. The aim of this study is to introduce the readers to the South China Sea, the situation surrounding it and its inference for world politics. Here, the South China Sea is interpreted as a deadlock. A conscious effort in this article is to explicitly address how the South China Sea impasse affects global politics instead of just the regional politics which is being emphasised by most scholars. In addition to dissecting its impact on world politics, the article also recommends ways in which the situation can be tackled. The first part of the article is introductory.

\section{LITERATURE REVIEW}

Politics, in its broadest sense, is the activity through which people make, preserve and amend the general rules under which they live. As such, politics is inextricably linked to the phenomena of conflict and cooperation. On the one hand, the existence of rival opinions, different wants, competing needs or opposing interests guarantees disagreement about the rules under which people live. On the other hand, people recognise that in order to influence these rules or ensure that they are upheld, they must work with others. This is why the heart of politics is often portrayed as a process of conflict-resolution, in which rival views or competing interests are reconciled with one another. However, politics in this broad sense is better thought of as a search for conflict-resolution than as its achievement, since not all conflicts are - or can be-resolved.

Nevertheless, when examined more closely, this broad definition of politics raises as many questions as it answers. For instance, does 'politics' refer to a particular way in which rules are made, preserved or amended (that is, peacefully, by debate), or to all such processes? Similarly, is politics practised in all social contexts and institutions or only in certain ones (that is, government and public life)? There are, in other words, a number of more specific definitions of politics; indeed, it sometimes appears that there are as many definitions as there are authorities willing to offer an opinion on the subject. The main definitions nevertheless can be broken down into four categories: politics as the art of government, politics as public affairs, politics as compromise, and politics as power. 
Dellios (2005) in his article, "The Rise of China as a Global Power", contends that the term global power is a more contemporary term for 'great power' and 'super power.' According to him, super power "was the creation of the politics of 20th century nuclear weapon technology, even though the coining of the term in 1944 did not take the nuclear dimension into account but rather the global reach of a nation." Furthermore, he argues that the term great power was a 19th century creation. As he puts it, "as the cold war became more entrenched, that which distinguished a nuclear super power from a 19th century great power was possession of the power of ultimate destruction and the strategic doctrine of nuclear deterrence that emerged from it." Though he does not clearly define what a global power is, he nevertheless gives the attributes of a global power. As he captures it, "beyond being merely 'great', or only 'super', they must now be global and attain transnational competencies that permit interaction with non-state actors, regional forums and the institutions of global governance. In short, a global power needs to promote international order, possess formidable military capability and the communicated will to use it, and engage productively in transnational projects such as global justice, as well as deal effectively with transnational threats such as militant religious extremists."

Dellios' (2005) attributes of a global power are in order; however, dealing effectively with transnational threats like terrorism as a yardstick to qualify as a global power is over-stretched. This is because these types of threats require collective actions of states to combat and are not only within the jurisdiction of one state to fight; otherwise, not even USA will be qualified to be called a global power. Shambaugh (2013) in his book, "China goes Global: The Partial Power" views global power from an angle not completely different from the view expressed by Dellios. Though he, like Dellios, does not expressly define what a global power is, it could be deduced from his work that a global power is one which can influence events in different parts of the world. Furthermore, Shambaugh enumerates the attributes of a global power as: global governance, global economic presence, cultural impact, global security presence and international identity (perception or image).

This study corroborates many of the views expressed by these scholars especially as they concern the attributes of a global power. It takes a global power to be economically, diplomatically, culturally and militarily sophisticated to influence outcomes and the will to establish world order.

\section{Theoretical Framework}

Power is defined as the ability of one actor to make another do something that it would not otherwise do. In realism, power is central to understanding every state's security strategy. The realist school of thought suggests that China's actions in the South China Sea are a function of the country's calculations regarding relative power and what is best for its own survival. Realism (that is, neorealism) sees the nature of international relations as defined primarily by its "ordering principle" - anarchy. The absence of a super state authority is akin to the state of nature that English political philosopher, Thomas Hobbes, refers to as "nasty, brutish, and short," which leads states to act self-reliantly regarding their own security (Brown, 2002). The realists see a fundamentally different mechanism; instead of conflict being shaped primarily by social factors, neorealists see conflict as the inevitable result of structural circumstances: international anarchy and power distribution (Waltz, 2002). 
Two large ideas dominate discussions of realism today: offensive and defensive. Offensive realists agree with classical realists that states will take every opportunity to increase their power where the benefits outweigh the costs (Lobell, 2016). Offensive realists see security as highly scarce in the international arena and therefore states are incentivized to adopt aggressive security strategies, because being the most powerful state in one's region or in the world is the best way to secure safety (Mearsheimer, 2002). Once a state has achieved preponderance in its neighbourhood, weaker states will be unlikely or unable to challenge the hegemon in any meaningful way, for fear of destruction. The defensive realist's understanding of states' behaviour is somewhat less pessimistic. For defensive realists, aggressive state behaviour is rarely beneficial because it only provokes counter balancing and results in overextension (Lobell, 2009). Aggression, to a defensive realist, can only be rationally justified when its positive outcome is near certain (Lobell, 2016). One state's attempt to increase its power will trigger a security dilemma for another state and can therefore push the other state to attack the first in an act of preemptive war. Thus, in defensive realist theory, a state is more likely to be interested in maintaining the status quo of the balance of power (Lobell, 2016). Here, maximizing power is secondary to maintaining a secure and stable position in the system (Waltz, 2002).

Given the South China Sea conflict, realists can expect that China's strategy in the region is based primarily on power dynamics. That being said, China's actions in the South China Sea lend themselves, superficially at least, more to the offensive realist's understandings of strategy.

\section{FINDINGS}

There is said to be ambiguity to what constitutes claims on the South China Sea, where states have accused China of complete claim over the sea. China in 2012 through the foreign ministry issued a statement that no country claims sovereignty over the entire sea, but some spratly "islands and adjacent waters." Such claims have made international law silent as there is no clarification of other states as what constitutes their ownership of the sea. It is also apparent that the only solution to claims and counterclaims of the South China Sea Island is the international law where lines can be drawn from the continental shelf that nears each and every conflicting member. Realists may hold the belief that China may not accept the claims of other states as they (other states) may not agree to the claims of China. This however, may be to conform with the principles of realism that states must acquire power to survive. China believes in one adage which states that "he who controls the wave controls the world" (Mark, Jon \& Noel, 1999).

China has about nine claims as it submitted to CLCS in 2009, which overlaps with Malaysian and Indonesian boundary claims founded in 1969, and Thailand in 1979. Philippines also has a claim which predates contemporary lines of claims, where lines were drawn by the Paris Treaty of 1898 which ceded Philippines to the United States, and in 2009, laws were formulated to update Philippines claims which are mostly in tandem with the Paris Treaty agreements. The claims of Vietnam have not been accepted by the international community and they have been referred back to 200 nautical miles of claims. The claims of Brunei are said to be within the legal framework internationally recognized as it does not demand for too many territorial or maritime possessions (Mark, Jon \& Noel, 1999). 


\section{Table 1.1: Resources in the South China Sea}

\section{Hydrocarbons}

\begin{tabular}{|l|l|}
\hline Region of South China Sea & Potential Oil and Gas Reserves \\
\hline Southern China & 1500 million barrels \\
\hline South of Hainan Island & 210 million barrels \\
\hline Gulf of Tonkin & 95 million barrels \\
\hline South Vietnam & 2847 million barrels \\
\hline Sunda Shelf & 180 million barrels \\
\hline Borneo/Sarawak & 9260 million barrels \\
\hline Philippines & 409 million barrels \\
\hline
\end{tabular}

Source: Swire Institute of Marine Science and Department of Ecology and Biodiversity, University of Hong

Kong: ftp://ftp.fisheries.ubc.ca/l.teh/destructive\%20fishing/South\%20china\%20sea.pdf

The above table shows how rich the South China Sea is and the reasons behind claims by the states that surround the sea. The world finds itself in an era of rapid population growth and scarcity of resources deepening with an alarming global warming. States seek to find areas of more strategic learning especially as it relates to energy security. The South China Sea is rich in oil, hence the conflict over the islands. Hydrocarbons are available in virtually all the above listed as well as huge oil reserves. It is in the argument of Xander (2012) that the oil reserve estimated in the South China Sea may be about $80 \%$ of the oil deposit of Saudi Arabia. This in the words of Xander (2012):

Though total estimates vary, the region is thought to contain oil reserves of at least 7.7 billion proven barrels, with more optimistic estimates reaching as high as 213 billion barrels. This is a huge sum, and if true, would be the equivalent of about 80 percent of the oil reserves of Saudi Arabia. The varied estimates demonstrate that no consensus has been formed on the numbers. Though Beijing has suggested the Spratly and Paracel Islands may also contain oil reserves, no reliable estimates have been on these areas either. However, many believe there to be a significant hydrocarbon prize in the region.

\section{Natural Gas}

According to Xander (2012), natural gas might be the most abundant and sought-after hydrocarbon resource in the South China Sea. Natural gas reserves are estimated to total around 266 trillion cubic feet and make up about 60-70 percent of the region's hydrocarbon resources. Indeed, most of the hydrocarbon fields explored in the exclusive economic zones of Brunei, Indonesia, Malaysia, Thailand, Vietnam, and the Philippines contain natural gas, not oil. As with oil, estimates of the region's natural gas resources vary widely. One Chinese estimate for the entire SCS estimates natural gas reserves to be 2 quadrillion cubic feet, with the hope that Beijing can produce 15 billion cubic meters of LNG a year. Yet, another Chinese report estimates 225 billion barrels of oil equivalent in the Spratly Islands alone. It is 
hypothetically possible therefore, that total gas resources (as opposed to proved reserves) in the South China Sea would be almost 900 trillion cubic feet (Tcf). This would be equivalent to the amount of natural gas in Qatar, which sits on the world's third largest reserves (Xander, 2012).

\section{CONCLUSION}

The South China Sea is increasingly a hotspot of conflict between China and the US; it is the subject of several overlapping territorial disputes. Like in most geopolitical tensions, trade would be a prime casualty in case of an escalation. And, as a new study finds, the consequences could be severe. Major trading economies in the Asia-Pacific region could suffer GDP loss if an escalation blocks shipping via key waterways in the region, as stated in the study by Kerem Coşar and Benjamin Thomas. It is not obscure to imagine a crisis that closes the South China Sea. The region is fraught with geopolitical tensions, including a dispute between China and Japan over the Senkaku Islands and overlapping claims involving China, Vietnam, the Philippines and Malaysia. If this happens, it is going to affect the entire world because a good amount of the world trade passes through that sea. If eventually this turns out to be a full-blown war, it will be another Cold War-US and its allies against China and its allies over the South China Sea. This would have an adverse effect on international politics and come with a handful of negativities, just like the Cold War did.

\section{RECOMMENDATIONS}

This paper recommends that China, the claimant of the South China Sea, and other countries involved should dialogue and come up with policies that are favourable to all parties involved.

China and the US should meet and diplomatically settle their scores to avoid another Cold War from happening. Joe Biden can start by revisiting his South China Sea policies that have a Cold War undertone.

\section{REFERENCES}

Almond, R.G. (2016). "South China Sea: The Case Against an ADIZ." The Diplomat. September 13, 2016. https://thediplomat.com/2016/09/south-china-sea-the- caseagainst-an-adiz/.

Bader, J.A. (2016). "How Xi Jinping Sees the World ... and Why." Brookings (blog).

February 11, 2016. https://www.brookings.edu/research/how-xi-jinping-sees-the-worldand- why/.

Baruah, D.M. "Second Thomas Shoal: The New Battleground." The Diplomat. Accessed March1, 2018. https://thediplomat.com/2014/04/second-thomas-shoal-the-newbattleground/.

Beckely, M. (2016). "Enforcing International Law In South China Sea: Can Southeast Asia Keep China In Check? - Analysis.” Eurasia Review (blog). October 6, 2016. http://www.eurasiareview.com/06102016-enforcing-international-law-in-south-chinasea-can- southeast-asia-keep-china-in-check-analysis/. 
Beukel, E. (2010). "China and the South China Sea: Two Faces of Power in the Rising China's Neighborhood Policy." Working Paper 2010:07. DIIS working paper. https://www.econstor.eu/handle/10419/44627.

Bilal, S.H. (2014). "Chinese ADIZ in South China Sea: A Strategic Move.” Defence Journal; Karachi 17 (7): 31-33.

Bin, Y. "Yu Bin’s Articles on Comparative Connections.” Accessed March 27, 2018. http://cc.csis.org/author/yu-bin/.

Blazevic, J.J. (2012). "Navigating the Security Dilemma: China, Vietnam, and the South China Sea." Journal of Current Southeast Asian Affairs 31 (4): 79-108.

Board, The Editorial. (2013). "Opinion | China's Evolving 'Core Interests." The New York Times, May 11, 2013, sec. Opinion.

https://www.nytimes.com/2013/05/12/opinion/sunday/chinas-evolving-coreinterests.html.

Breslin, S. et al.(2014). International Relations of China. 8 vols. London: SAGE Publications Ltd. http://sk.sagepub.com/navigator/international- relations-ofchina.

Brown, A. et al. (2002). Critical realism and Marxism. Psychology Press.

Dellios, R. (2005). The rise of China as a global power. Culture Mandala, 6(2), 5862.

Dellios, R., \& Ferguson, R. J. (2012). China's quest for global order: from peaceful rise to harmonious world. Lexington Books.

Geunwook L.G. (2002). To be long or not to be long that is the question: The contradiction of time-horizon in offensive realism: John J. Mearsheimer, The Tragedy of Great Power Politics (New York: Norton, 2001). Security Studies, 12(2), 196-217.

Lobell, S. E., Ripsman, N. M., Taliaferro, J. W., \& Taliaferro, J. W. (Eds.). (2009). Neoclassical realism, the state, and foreign policy. Cambridge University Press.

Mark, J. V., Jon, M. V.D. and Noel, A. L. (1999). Sharing the Resources of the South China. Honolulu, University of Hawaii Press

Ripsman, N. M., Taliaferro, J. W., \& Lobell, S. E. (2016). Neoclassical realist theory of international politics. Oxford University Press.

Shambaugh, D. L. (2013). China goes global: The partial power (Vol. 409). Oxford: Oxford University Press.

Telbami, S. (2002). Kenneth Waltz, neorealism, and foreign policy. Security Studies, 11(3), $158-170$.

Toft, P. (2005). John J. Mearsheimer: an offensive realist between geopolitics and power. Journal of International Relations and Development, 8(4), 381-408.

Xander, V. (2012). Resources in the South China Sea. American Security Project, 04 December. https://www.americansecurityproject.org/resources-in-the-south-china-sea/ 